\title{
Paraleyrodes minei Iaccarino 1990 (Homoptera: Aleyrodidae), new specie for Italy, on Citrus aurantium L., 1758
}

\begin{abstract}
The nesting whitefly Paraleyrodes minei Iaccarino 1990 (Homoptera: Aleyrodidae) was found on leaves of sour orange tree Citrus aurantium L., 1758, in the Gussone Park of the Faculty of Agriculture, of the University of Naples "Federico II", at Portici, Italy.

Riassunto - Paraleyrodes minei Iaccarino 1990 (Homoptera: Aleyrodidae), una nuova specie per l'Italia, su Citrus aurantium Linneo 1758, in Italia.

Paraleyrodes minei Iaccarino 1990 (Homoptera: Aleyrodidae) è stato ritrovato su foglie di arancio amaro, Citrus aurantium L., 1758, nel Parco Gussone della Facoltà di Agraria, dell'Università di Napoli, in Portici, Italia.
\end{abstract}

Key Words: aedeagus, Aleurodicinae, antenna, pores, western Palaearctic.

\section{INTRODUCTION}

The nesting whitefly Paraleyrodes minei Iaccarino 1990 belongs to the subfamily Aleurodicinae Quaintance et Baker, characterized by adults with forewings displaying a median and a forked radial vein and the legs with a tarsal paronychium like a spine. The immature stages present compound-style pores in addition to simple ones, legs with a terminal claw and the lingula extended beyond the posterior margin of the vasiform orifice and with 2 apical setae pairs (Quaintance et Baker, 1913; Bondar, 1923; Evans et al., 2006; Evans, 2008). The operculum partially covers the lingula and the vasiform orifice.

The genus Paraleyrodes Quaintance 1909 is distinguished from other genera of the subfamily, to have the unforked radial sector and 4 antennal articles in the female and 3 in the male (Quaintance, 1909; Quaintance et Baker, 1913; Bondar, 1923; Iaccarino, 1990; Martin, 1999, 2004; Evans et al., 2006, Evans, 2008).

The $P$. minei has been reported, for the Western Palaearctic region, in Iran, Israel, Lebanon, Madeira, Malaga, Morocco, Spain, Syria ${ }^{(1)}$ and Turkey (Iaccarino, 1990; Garcia

(1) Russell L.M. (personal correspondence, 1989) told that the species was certainly already present in the USA, but it was not reported because confused with other species of Paraleyrodes genus; in fact Belows 
Garcia et al., 1992; Llorens Climent et Garrido Vivas, 1992; Argov, 1994; Aguiar et Pita, 1996; Martin et al., 2000, Martin, 2004; Ghahani et al., 2009).

\section{MATERIAL AND METHODS}

The specimens, including several life stages, (some eggs and $2^{\text {nd }}$ larval instars, two $3^{\text {rd }}$ larval instars, 8 pupal cases, 1 male and 5 females,) were collected from leaves of sour orange tree in the Gussone Park of the Faculty of Agriculture of the University of Naples "Federico II" at Portici, Italy at the end of 2010. This host plant was also infested by Aleurothrixus floccosus (Maskell 1895) and the different type and form of wax secreted by the 2 whiteflies has facilitated its recognition. The samples were placed in a $10 \%$ potassium hydroxide solution for the maceration of the internal organs and then in glacial acetic acid to neutralize $\mathrm{KOH}$ and remove any fat substances. The dehydration was performed with a first step in $50 \%$ phenol and a second in $100 \%$ phenol. The Canada Balsam-phenol solution was used for slides mounting. The dissection of the adults was carried out during the transfer in pure phenol.

\section{RESULTS}

\section{Adult}

Female: pale yellow in colour with some white powdery wax covering the body, especially the wings; 4 antennal articles (Fig. 1 A); sub-pyriform abdomen with 4 pairs of ventral wax plates.

Male: similar to female; 3 antennal articles (Fig. 1 B); abdomen with three pairs of ventral wax plates; stumpy claspers ending in a sharp nail; aedeagus with the "cock head" shaped apex, with 3 short appendixes located on upper and posterior surface, 2 long and thin appendixes below an anterior short appendix ${ }^{(2)}$ (Fig. 1 C) (Iaccarino, 1990; Martin, 1996; Evans et al, 2006).

Immature stages

Egg: suboval, covered with powdery white waxy secretion, attached to leaf by long pedicel, which gradually bending to set down the egg on the leaf surface.

Neanid I (crawler): subelliptic with a hyaline wax fringe along the marginal area, where, as in all other stages, there are numerous simple pores, and a thin band of white flocculent wax on the dorsum, from the thorax to the abdomen.

Neanid II: suboval, with a fringe of short hyaline wax rods along the margin and

et al., 1998 reported that Paraleyrodes minei was first noted in 1984 in San Diego and the California Plant Pest and Disease Report, 1991 and 1992, that it was first collected in San Diego County in 1985 as reported in CPPDR , 1985 it was recorded as Paraleyrodes sp. undescribed.

(2) The reduced number of antennal articles, in both sexes, and the unforked radial sector of the wings are two fundamental characters to separate this genus from the others; the typical shape of the aedeagus allows for easy separation of this species from others. 


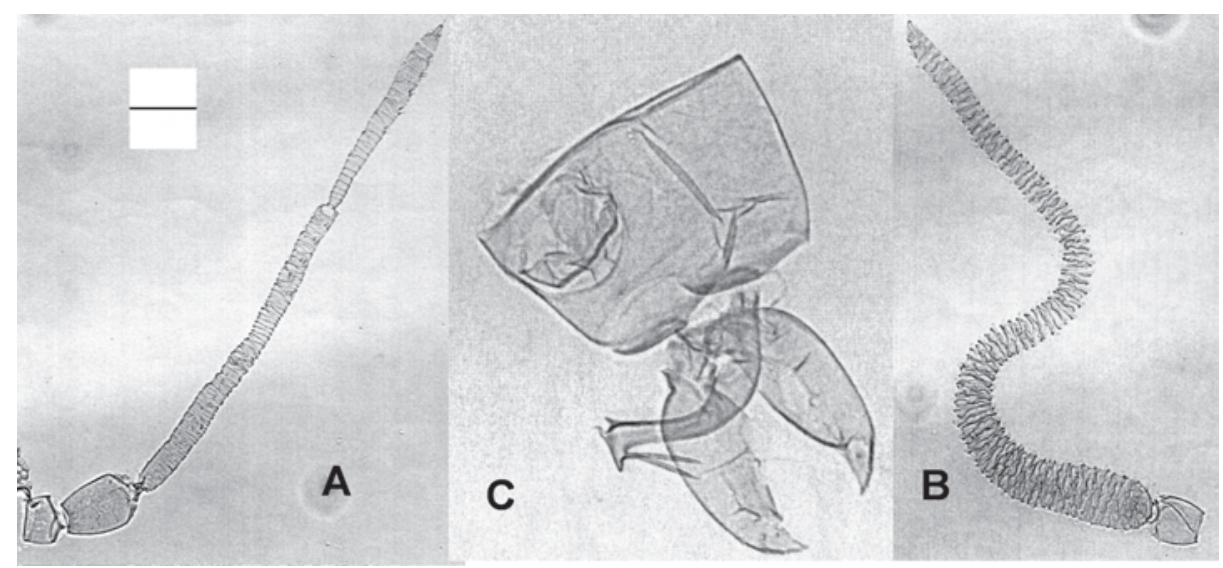

Fig. 1 - Paraleyrodes minei, adulto: A, female antenna; B, male antenna; C, aedeagus. Scale bar represents $63 \_\mathrm{m}$ in $\mathrm{A}, 79 \_\mathrm{m}$ in $\mathrm{B}$ and $45 \_\mathrm{m}$ in $\mathrm{C}$.

with white wax rods arising from 2 pairs of compound pores, posterior one and the anterior others.

Neanid III: subelliptic, with marginal fringe and with 2 wax rods, produced by 2 pairs of compound pores located on the thorax (Fig. 2 B).

Pupal case (Fig. 2 A): subelliptic, marginally fringed with 5 compound pores pairs: a single pair of cephalic and 4 pairs of abdominal pores, from $5^{\text {th }}$ to $8^{\text {th }}$ segment (Fig. 2 D.i), each of them secreting single white wax rods upward that, then, break, falling all around the pupal case, and, as for the other stages, with a crown shaped appearance ${ }^{(3)}$. Two pairs of compound pores smaller are present on $3^{\text {rd }}$ and $4^{\text {th }}$ abdominal segments (Fig. 2 D.ii). Thorax with two pairs of "cicatrices" scars of compound pores found in the $3^{\text {rd }}$ instar (Fig. 2 D.iii). A pair of hairs is located on anterior and another one on posterior margin; a single cephalic pair of setae, and other two pairs, the former on $1^{\text {st }}$ and the latter on $8^{\text {th }}$ abdominal segment on side of the vasiform depression. Finally 14 setae, on every side, alternate, irregularly, to the numerous simple wax pores are located on the margin. The lingula, spatulate-globose, exserted, and its tip presents two pairs of long setae (Fig. 2 C) (Iaccarino, 1990; Martin, 1996; Martin et al., 2000).

(3) For separating the P. minei pupal case from those ones of the major species that commonly infest Citrus in Italy, it is useful to consider the presence and type of wax: long cylindrical rods in $P$. minei, abundant and flocculent in Aleurothrixus floccosus (Maskell 1895), hyaline marginal band in Parabemisia myricae (Kuwana 1927) (It can also be found on the upper leaves surface), without wax in Bemisia afer (Priesner et Honsy 1934) and in Dialeurodes citri (Asmead 1885) (It is often larger than pupal case of previous species). 


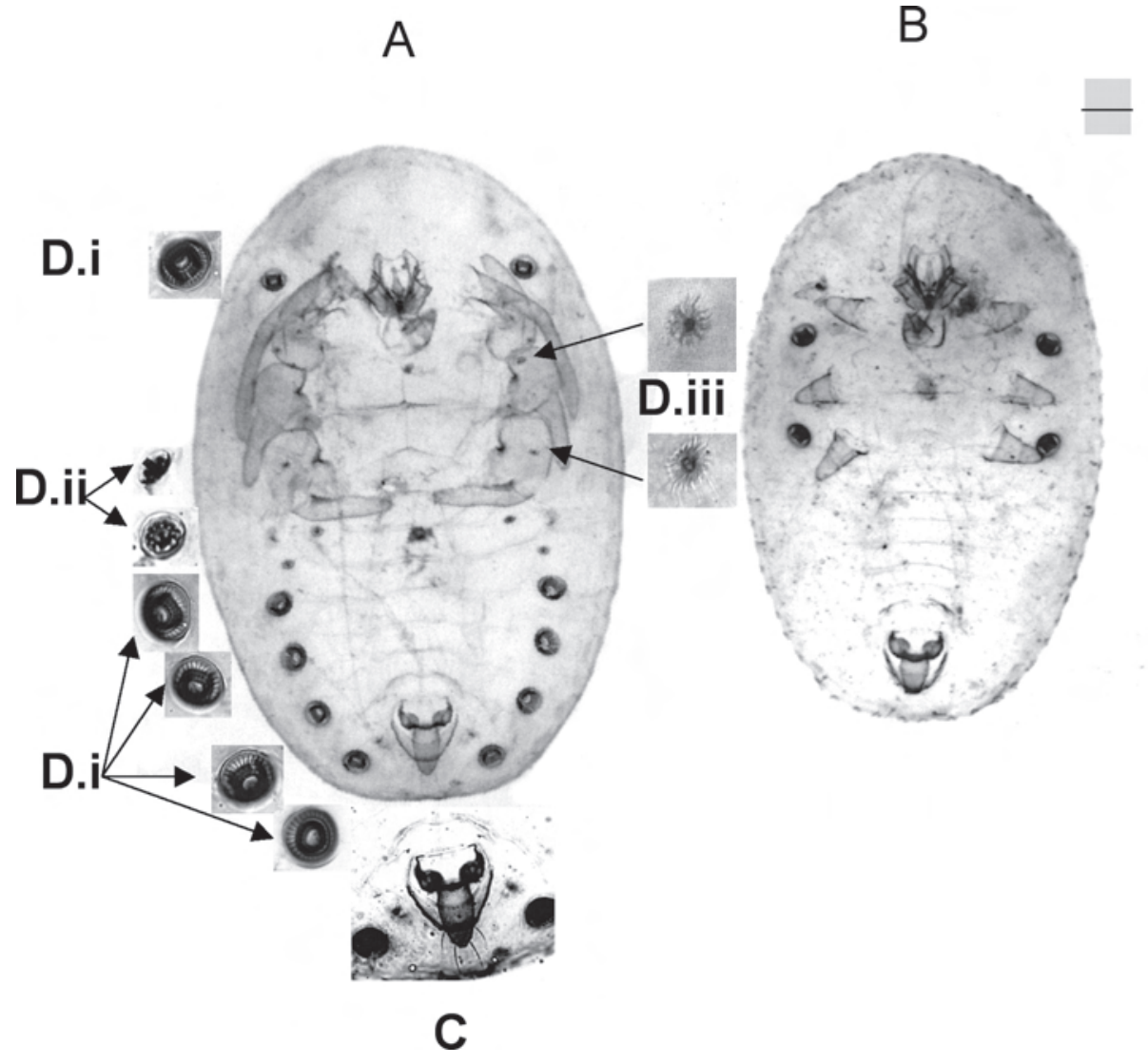

Fig. 2 - Paraleyrodes minei, Immature stages: A, pupal case; B, neanide III; C, vasiform orifice; $\mathrm{D}, \mathrm{i}$ large compound pore, ii small compound pore, iii cicatrice. Scale bar represents 59 _m in A, $45 \_\mathrm{m}$ in B, $45 \_\mathrm{m}$ in C, $50 \_\mathrm{m}$ in D.i, $29 \_\mathrm{m}$ in D.ii and 32 _m in D.iii.

\section{DISCUSSION}

The adult females lay eggs pale yellow usually surrounded, especially in heavy infestation, by annular fluffy wax secreted by the adults and so they appear to be in a white "nest" of woolly wax. The crawlers can remain in the nests, so the neanides of the following stages will add the flocculent wax rods, or emerge from the nests and have only the characteristic rods in a circular pattern (Iaccarino, 1990).

In Spain, in laboratory trials at room temperature, on lemon leaves, $P$. minei has developed three generations per year (Garcia Garcia et al., 1992), while in California, in field trials, on orange leaves, the generations were four per year. Population development 
is continuous throughout the year, albeit it has lower trophic activity in adverse time (Bellows et al., 1998).

In the Mediterranean basin the host plants belong to the genus Citrus L. 1758 (Iaccarino, 1990; Martin, 1996; Evans, 2007b; Evans, 2008). In other areas (Belize, Benin, Bermuda, Guatemala, Honduras, Hong Kong, Mexico, Puerto Rico and USA) $P$. minei is polyphagous and is found on Anonaceae, Apocynaceae, Araceae, Arecaceae, Asteraceae, Compositae, Ericaceae, Euphorbiaceae, Lauraceae, Myrtaceae, Piperaceae, Poligonaceae, Rhizophoraceae, Rubiaceae and Rutaceae ( Martin et al., 2000; Evans, 2008). The natural enemies reported are the predatories Clitostetus arcuatus (Rossi 1794) and Serangium parcesetosum Sicari 1929 (Coccinellidae), and the parasitoids Encarsia dominicana Evans et Serra 2002, E. parvella Silvestri 1929, E. variegata Howard 1908 and E. sp., (Aphenidae) (Evans, 2007a, Evans, 2008).

\section{REFERENCES}

Aguiar A.M.F., Pita M.T., 1966 - Contribution the knowledge of the whiteflies (Hom.:Aleyr.) from Madeira island.- Boletim do Museu Municipal do Funchal, Supl. 4: 285-309.

Argov Y., 1994 - The woolly, a new pest in Israel. - Alon Hanotea, 48: 290-292.

California Plant Pest and Disease Report - 1985 - Department of Food and Agriculture 4 (4): 101118. http://www.cdfa.ca.gov/phpps/ppd/publications/CPPDR.html

California Plant Pest and Disease Report - 1991- Department of Food and Agriculture 10 (1-2): 1-29. http://www.cdfa.ca.gov/phpps/ppd/publications/CPPDR.html

California Plant Pest and Disease Report - 1992 - Department of Food and Agriculture 11(5-6): 59-93. http://www.cdfa.ca.gov/phpps/ppd/publications/CPPDR.html

Bellows JR. T.S., Meisenbacher C., Headrick D.H., 1998 - Population ecology field biology of Paraleyrodes minei (Hom.:Aleyr.) in southern California. - Enviromental Entomology, 27(2): 277-281.

Bondar G., 1923 - Aleyrodideos do Brasil. - Official State Publisher. Bahia, pp. 182.

Evans G.A., 2007a - Parasitoids (Hym.) associated with whiteflies (Aleyr.) of the world.-APHIS Computer Version, pp.173. http://www.sel.barc.usda.gov:591/1WF/parasitoidcatalog.pdf.

Evans G.A., 2007b - Host plant list of the whiteflies (Aleyr.) of the world. - APHIS Computer Version, pp. 290. http://www.sel.barc.usda.gov:591/1WF/WhiteflyHost.pdf

Evans G.A., 2008 - The whiteflies (Hem.:Aleyr.) of the world and their host plants and natural enemies.- APHIS Computer Version, pp.703. http://www.sel.barc.usda.gov:591/1WF/WorldWhitefly-Catalog.pdf

Evans G.A., Dooley J., Gill R., 2006 - Hawaiian whiteflies (Aleyr.). - Homoptera Workshop. Unpublished, pp. 51.

Garcia Garcia E.J., Garijo Alba C., Garcia Segua S., 1992 - Presenza de Paraleyrodes sp. pr. citri (Bondar, 1931) (Insecta:Hom.:Aleyr.) en los cultivos de citricos de la provincia de Malaga (sue de Espana): Aspectos biologicos y ecologicos de la plaga. - Boletin de Sanidad vegetal, Plagas, 18: 3-9.

Ghahari H., AbD-Rabour S., Zahradnik J., Ostovan H., 2009 - Annotated catalogue of whiteflies (Hem.:Stern.:Aleyr.) from Arasbaran, northwestern Iran. - Journal of Entomology and Nematology, 1(1): 7-18.

IACCARINO F.M., 1990 - Descrizione di Paraleyrodes minei n.sp. (Hom.:Aleyr.), nuovo aleirodide 
degli agrumi, in Siria. - Bollettino del Laboratorio di Entomologia Agraria "Filippo Silvestri" di Portici, 46(1989): 131-149.

Llorens Climent J.M., Garrido Vivas A., 1992 - Homoptera III. Mosca blancas y sus controllo biologico. Pp. 203. Alicante. Pisa Ediciones.

Martin J.H., 1996 - Neotropical whiteflies of the subamily Aleurodicinae estabilished in the western Paleartictc (Hom.:Aleyr.). - Journal of Natural History, 30: 1849-1859.

Martin J.H., 2004 - Whiteflies of Belize (Hem.:Aleyr.). Part 1. Introduction and account of the subfamily Aleurodicinae Quaintance \& Baker. - Zootaxa, 681: 1-199.

Martin J.H., Mifsud D., RAPISARDA C., 2000. - The whiteflies (Hem.:Aleyr.) of Europe and the Mediterranean basin. - Bulletin of Entomological Research, 90: 407-448.

QuaINTANCE A.L., 1909 - A new genus of Aleyrodidae, with an Aleyrodes nubifere Berger and Aleyrodes citri Riley and Haward. - United States Department of Agriculture, Bureau of Entomology, Technical Service, 12 (IX): 169-174.

Quaintance A.L., BaKer A.C., 1913 - Classification of the Aleyrodidae. Part.1. United States Department of Agriculture, Bureau of Entomology, Technical Service, 27: 1-93.

Ulusoy M.R., UYGUN N., 1996 - Dogu Akdeniz Bolgesi turuncgillerinde potansiyel iki yeni zararli: Aleurothrixus floccosus (Maskell) ve Paraleyrodes minei Iaccarino (Hom.:Aleyr.). - Turkiye Entomoloji Dergisi, 202 : 113-121.

FABIO M. IACCARINO - Dipartimento di Entomologia e Zoologia Agraria "F.Silvestri, Università degli Studi di Napoli "Federico II", Facoltà di Agraria, via Università 100 - 80055 Portici (Napoli), Italy. E-mail fiaccari@unina.it.

RicCARdo Jesu, Rosa GiacometTi - Dipartimento di Entomologia e Zoologia Agraria "F. Silvestri, Università degli Studi di Napoli "Federico II", Facoltà di Agraria, via Università, 100 - 80055 Portici (Napoli), Italy. 